\title{
KARAKTERISTIK STOMATA PADA POHON DI RUANG TERBUKA HIJAU UNIVERSITAS TANJUNGPURA KOTA PONTIANAK
}

\author{
( Characteristics of Tree Stomata in Green open spaces University Tanjungpura in Pontianak)
}

\author{
Anita Putriani, HariPrayogo, Reine Suci Wulandari \\ Fakultas Kehutanan Universitas Tanjungpura Jalan Daya Nasional Pontianak 78124 \\ E-mail: Putri.p2015@gmail.com
}

\begin{abstract}
The purpose of this study was to describe the stomata found in pulai, mahang, saga, white meranti and ketapang plants in the green space area. This study uses a descriptive method to describe stomatal characteristics such as stomatal type, stomata size and number of stomata in perennials, mahang, saga, ketapang and white meranti. The study was conducted in two green open areas, namely the Untara Sylva Arboretum and in the public green open area. Length of stomata observation for 2 weeks. Overall the results of the observations obtained 4 (four) types of stomata that are the same in the two regions. The types of stomata are anisocytic in Pulai (Alstonia scholaris), anomosytic in mahang (Macaranga pruinosa), parasitic in saga (Adenanthera pavonina), pickled on white meranti (Shorea bracteolata), anisocytic on ketapang (Terminalia cattapa). In the Sylva Arboretum area, Untan, plant origin has a stomata number of 15 with stomata size of $14.1 \mu \mathrm{m}$, stomatal hole $8.03 \mu \mathrm{m}$ and neighboring cells $14.7 \mu \mathrm{m}$. In the green open space area of the plant, there were ketapang plants had 35 stomata with a stomata size of 16.03 $\mu m$, a stomata hole of 8.03 and a neighboring cell of 6.57. the stomata structure shows that the leaves found in the arboretum region have large stomata while the outside of the general green open space has a small stomata. Different conditions of light and temperature greatly influence the variation in numbers on the size of the stomata, stomatal holes and neighboring cells. The farther the distance between plants and crowded places the more the size of the stomata decreases.
\end{abstract}

Keywords: green open space, number of stomata, stomatal types, trees

PENDAHULUAN

Tumbuhan tersusun dari berbagai organ seperti akar, batang, daun. Daun merupakan organ terpenting bagi tumbuhan dalam melangsungkan hidupnya. Pada daun terdapat stomata yang berfungsi untuk pertukaran gas. Daun biasanya tipis melebar kaya akan suatu zat warna hijau yang dinamakan klorofil. Daun memiliki beberapa fungsi antara lain pengambilan zat-zat makanan (resorbsi), pengolahan zat-zat makanan (asimilasi), penguapan air (transpirasi), pernafasan (respirasi).
Menurut Fahn (1991) stomata yang dimiliki tumbuhan berbeda-beda, baik bentuk dan posisinya. Stomata biasanya ditemukan pada bagian tumbuhan yang berhubungan dengan udara terutama di daun, batang dan rizoma.Stomata umumnya terdapat pada bagian bawah daun, tetapi ada beberapa jenis tumbuhan, stomata dapat dijumpai pada permukaan atas dan bawah daun. Menurut Lakitan (1993) bentuk atau tipe stomata dibedakan atas empat yaitu anomositik, anisositik, parasitik dan diasitik. Menurut Sri Haryanti (2010), 
fungsi, bentuk, ukuran dan susunan selsel epidermis tidaklah sama atau berbeda pada berbagai jenis tumbuhan, demikian juga dengan bentuk atau tipe stomata .

Stomata memiliki beberapa tipe yang dapat mempengaruhi terjadinya proses transpirasi ataupun proses keluar masuknya gas ataupun air dari lingkungan ke dalam sel (Khoiroh dkk, 2014). Jika dibedakan berdasarkan letak penebalan pada sel penutupnya dibagi menjadi beberapa jenis, yaitu tipe amaryllidaceae, helleborus, dan graminea. RTH seperti Arboretum Sylva Indonesia Universitas Tanjungpura Kota Pontianak merupakan kawasan pelestarian plasama nutfah di Kalimantan Barat, yang dibangun dengan tujuan sebagai tempat pengembangan keanekaragaman hayati, serta untuk pengembangan hutan kota, untuk sarana rekreasi dan hiburan bagi masyarakat. Arboretum ini mempunyai fungsi utamasebagai kawasan konservasi jenis-jenis flora endemik Kalimantan Barat. Beberapa flora di kawasan ini seperti tanaman pulai, mahang, saga, meranti putih dan ketapang.

Stomata merupakan salah satu bagian dari organ daun yang umumnya berada di jaringan epidermis baik epidermis atas ataupun epidermis bawah. Posisi stomata antara daun yang satu dengan daun yang lainnya tidak sama. Hal ini disebabkan karena perbedaan luas permukaan daun pada tanaman, penutupan stomata, jumlah dan ukuran stomata, perbedaan bentuk stomata, jumlah daun, kerapatan stomata dan perilaku stomata. Faktor eksternal yang dapat mempengaruhi stomata pada tumbuhan didominasi oleh radiasi matahari, suhu dan temperatur. Sampai saat ini belum diketahui variasi stomata pada beberapa jenis tumbuhan yang terdapat di Arboretum Sylva Indonesia Universitas Tanjungpura dan RTH umum. Tujuan dari penelitian ini adalah untuk mendeskripsikan karakteristik stomata tipe-tipe stomata yang terdapat pada tanaman pulai, mahang, saga, meranti putih dan ketapang di Kawasan Ruang Terbuka Hijau.

\section{METODE PENELITIAN}

Penelitian dilaksanakan pada kawasan RTH yaitu di Arboretum Sylva Universitas Tanjungpura Pontianak dan Ruang Terbuka Hijau umum. Setelah pengambilan sampel daun pada 2 kawasan tersebut daun diamati di Laboratorium Silvikultur Fakultas Kehutanan Untan. Waktu penelitian dilakukan selama lebih kurang 3 (Tiga) bulan.

\section{Prosedur Penelitian}

Tahapan persiapan

Kegiatan awal yang dilakukan yaitu survei lapangan dimana untuk menentukan lokasi pengamatan lokasi yang dipilih adalah tempat tumbuh tanaman pulai, mahang, saga, ketapang dan meranti putih di 2 kawasan RTH tiap kawasan diambil 1 (satu) sampel pohon. Selain itu persiapan peralatan juga dilakukan. Kegiatan yang dilakukan berupa pengamatan serta pengambilan sampel daun di lapangan.

Pengambilan Sampel Daun

Pengambilan sampel dilakukan pada pagi hari jam sekitar jam 09.00. Sampel 
yang diambil adalah daun pada batangyang telah berkembang sempurna masih mulus tidak ada cacat. Daun dipakai sebagai sampel untuk dibuat irisan preparat memanjang permukaan bawah daun.

Tahap pembuatan preparat

a. mengumpulkan alat dan bahan yang akan digunakan untuk penelitian seperti kamera mikroskop, pisau, kaca objek, kaca preparat, kertas label, guntung, air dan kuteks.

b. helaian daun dengan dibersihkan menggunakan tisu untuk menghilangkan kotoran.

c. kutek transparan permukaan dioleskan pada daun di bagian tengahnya dan di biarkan sampai kering.

d. menempelkan permukaan daun yang sudah diolesi dengan kutek transparan menggunakan isolatip transparan.

e. isolatip dengan cara memijat permukaan daun dengan menggunakan jari tangan, agar

kutek menempel dengan baik pada isolatip.

f. isolatip dikelupas secara perlahan dan menempelkan pada gelas objek.

g. meratakan dan memberikan kertas label pada sebelah kiri dengan memberi keterangan.

h. kemudian mengamati tipe-tipe stomata di bawah mikroskop cahaya sampai obyek

teramati dengan jelas.
Pengamatan

Pengamatan dilakukan terhadap preparat stomata yang meliputi tipe stomata, ukuran stomata, dan jumlah stomata.

\section{Analisis Data}

Analisa data dilakukan secara deskriptif dan selanjutnya ditampilkan dalam bentuk foto untuk menggambarkan tipe stomata, ukuran stomata dan jumlah stomata pada tumbuhan pulai, mahang, saga, ketapang danmeranti putih. Analisa karakteristik stomata mengunakan jurnal yang berkaitan dengan stomata.

\section{HASIL DAN PEMBAHASAN}

\section{Tipe-tipe stomata pada 5 jenis}

\section{tanaman}

Hasil pengamatan terhadap stomata menunjukkan bahwa setiap spesies tanaman (pulai, mahang, saga, meranti putih dan ketapang) mempunyai tipe stomata yang berbeda-beda.. Tipe-tipe stomata tersebut adalah anisositik pada pulai (Alstonia scholaris), anomositik pada mahang (Macaranga pruinosa), parasitik pada saga (Adenanthera pavonina), diasitik pada meranti putih (Shorea bracteolata), anisositik pada ketapang (Terminalia cattapa). Karakteristik stomata pada kawasan Arboretum Sylva Untan dan RTH umum dapat dilihat pada Tabel 1. 
Tabel 1. Karakteristik stomata pada kawasan RTH ( Stomata characteristics in open green areas)

\begin{tabular}{|c|c|c|c|c|c|c|}
\hline \multirow[t]{2}{*}{ No } & \multirow[t]{2}{*}{ Lokasi } & \multirow[t]{2}{*}{ Nama Pohon } & \multicolumn{3}{|c|}{ Karakteristik Stomata } & \multirow[t]{2}{*}{ Tipe } \\
\hline & & & $\begin{array}{l}\text { Ukuran } \\
\text { Stomata }\end{array}$ & Lubang Stomata & $\begin{array}{l}\text { Ukuran Sel } \\
\text { Tetangga }\end{array}$ & \\
\hline 1 & & Pulai & 14,1 & 8,03 & 14,7 & Anisositik \\
\hline 2 & ARBORETUM & Mahang & 2,71 & 1,17 & 1,32 & Anomositik \\
\hline 3 & & Saga & 2,68 & 1,34 & 1,41 & Diasitik \\
\hline 4 & & Meranti Putih & 20,6 & 9,21 & 7,36 & Parasitik \\
\hline 5 & & Ketapang & 13,3 & 6,75 & 6,42 & Anisositik \\
\hline 6 & RUANG & Pulai & 2,83 & 1,65 & 1,25 & Anisositik \\
\hline 7 & TERBUKA & Mahang & 1,56 & 0,86 & 1,17 & Anomositik \\
\hline 8 & HIJAU & Saga & 2,46 & 1,37 & 1,78 & Diasitik \\
\hline 9 & & Meranti Putih & 6,23 & 3,4 & 3,94 & Parasitik \\
\hline 10 & & Ketapang & 16,03 & 8,03 & 6,57 & Anisositik \\
\hline
\end{tabular}

Pada Tabel 1 menjelaskan tentang karakteristik stomata pada kawasan RTH Pada pulai tipe ini di tunjukkan dengan sebaran stomata yang berada di atas permukaan daun. stomata dikelilingi tiga sel tetangga yang dirata-ratakan sama besar. Pada daun pulai memiliki ukuran stomata $14,1 \mu \mathrm{m}$, lobang stomata $8,03 \mu \mathrm{m}$ dan sel tetangga $14,7 \mu \mathrm{m}$. Menurut Faiza Khan et.al. (2014) bahwa karakteristik ini menyatakan bahwa tipe stomata pada pulai adalah tipe aninositik. Stomata yang terdapat pada pulai di kawasan arboretum sylva untan didapatkan hasil stomata yag sedikit. Jumlah stomata yang sedikit dapat dipengaruhi oleh faktor seperti ukuran daun, tebal tipisnya daun, banyak sedikitnya bulu pada permukaan bulu pada permukaan daun (Dwidjoseputro 1994). Tebal daun juga mempengaruhi dalam pembuatan preparat ditambah denganjenis daunnya yang bergetah dan dilakukan berulang kali untuk mendapatkan tipe stomata pada tanaman ini.

Pada mahang tipe ini ditunjukkan dengan sebaran stomata yang dengan jumlah yang dirata-rata kan dengan ciri sel penutup dikelilingi oleh sejumlah sel yang sama bentuk dan ukurannya dari sel epidermis lainnya. Pada tanaman mahang memiliki ukuran stomata 2,71 $\mu \mathrm{m}$, lobang stomata $1,17 \mu \mathrm{m}$ dan sel tetangga $1,32 \mu \mathrm{m}$.Pengamatan hasil stomata pada daun mahang yang diamati juga perlu dilakukan secara berulang kali di sebabkan daun yang sangat tipis dan terdapat banyak serat.Stomata yang terdapat pada daun yang diamati ini tidak banyak, lebarnya daun mahang hanya diambil sampel daunnya yang sedikit untuk melihat tipe stomata yang terdapat pada tanaman mahang.

Pada saga tipe ini ditunjukkan dengan debaran stomata yang memiliki yang dikelilingi oleh 2 sel tetangga. Dinding bersama dari kedua tetangga tegak lurus terhadap sumbu pajang sel penutup serta celah. Pada tanaman saga memiliki ukuran stomata 2,68 $\mu \mathrm{m}$, lobang stomata $\mu \mathrm{m}$ dan sel tetangga 1,41 $\mu \mathrm{m}$. Stomata yang terdapat pada tanaman saga yang diamati itu banyak, dilihat dari hasil preparat yang diamati. Mendapatkan stomata pada saga tidak 
terlalu sulit karena daun yang tidak seperti pada daun mahang.

Pada tanaman meranti putih di tunjukkan sebaran stomata yang memiliki tipe stomata yang memiliki tipe stomata parasitik yang ditandai dengan satu atau lebih sel tetangga serta sumbu membujurnya sejajar dengan sumbu sel pejanga yang hasilnya di rata-ratakan. Pada tanaman meranti putih ukuran stomata 20,6 $\mu \mathrm{m}$, lobang stomata 9,21 $\mu \mathrm{m}$ dan sel tetangga $7,36 \mu \mathrm{m}$. Stomata yang diamati pada tanaman ini terdapat banyak stomata. Tanaman ketapang memiliki ukuran stomata $13,3 \mu \mathrm{m}$, lobang stomata $6,75 \mu \mathrm{m}$ dan sel tetangga 6,42 $\mu \mathrm{m}$. Dari hasil pengamatan daun yang diamati jumlah stomatnya banyak, dikarenakan lebarnya daun pada tanaman ketapang.

Pada RTH umum memiliki tipe stomata yang sama dengan kawasan arboretum hanya saja yang membedaakannya ukuran stomata, lobang stomata dan sel tetangga, dapat dilihat di table 1 bahwa pada tanaman pulai ukuran stomata $2,83 \mu \mathrm{m}$, lobang stomata $1,65 \mu \mathrm{m}$ dan sel tetangga 1,25 $\mu \mathrm{m}$. Pada tanaman mahang ukuran stomata $1,56 \mu \mathrm{m}$, lobang stomata 0,86 $\mu \mathrm{m}$ dan sel tetangga $1,17 \mu \mathrm{m}$. Tanaman saga memiliki ukuran stomata $2,46 \mu \mathrm{m}$, lobang stomata $1,37 \mu \mathrm{m}$ dan sel tetangga 1,78. Meranti putih ukuran stomata 6,23 $\mu \mathrm{m}$, lobang stomata $3,4 \mu \mathrm{m}$ dan sel tetangga 3,94. Pada tanaman ketapang ukuran stomata $16,03 \mu \mathrm{m}$, lobang stomata 8,03 dan sel tetangga 6,57.

Karakteristik stomata pada kawasan arboretum dan ruang terbuka hijau umum menunjukkan bahwa adanya variasi angka pada ukuran stomata. Keadaan cahaya dan suhu yang berbeda sangat pengaruhi adanya variasi angka pada ukuran stomata.. Terlihat dari stomata yang berada di kawasan arboretum dan umum menunjukkan bahwa lebih besar ukuran stomata dibandingkan di kawasan ruang terbuka hijau. Lingkungan dapat berperan penting dalam menentukan jumlah stomata. Selain faktor lingkungan seperti intensitas cahaya, suhu, dan kelembaban udara, banyaknya stomata yang membuka juga di pengaruhi dengan tingkat vegetasi dan kerapatan tanaman tersebut. Intensitas cahaya merupakan salah satu faktor lingkungan yang mempengaruhi luas permukaan daun, jumlah dan ukuran stomata menurut Marpaung et al., (2013) Wahyuningsih et al. (2006) menyatakan bahwa daun pada tumbuhan yang terpapar cahaya dengan intensitas tinggimempunyai stomata lebih kecil serta jumlahnya banyak dibandingkan dengan yang tumbuh ditempat naungan dan lembab. Selain itu, jumlah dan ukuran stomata juga dipengaruhi tempat tanaman tumbuh menurut Tambaru (2013). Pernyataan ini di dukung oleh Padmaningrum et al. (2014) bahwa tanaman teratai tidak cocok ditanam di lokasi tercemar karena secara fisiologi tidak mampu mengabsorbsi karbondioksida secara optimum dan tidak tahan terhadap pencemaran air. Jumlah dan ukuran stomata juga dipengaruhi aktivitas meristematik yang 
mengakibatkan helaian daun bertambah (Hidayat, 1995).

\section{KESIMPULAN}

Penelitian ini dapat disimpulkan bahwa terdapat tipe stomata yang berbeda pada kelima jenis tanaman yang berada di kawasan arboretum dan diluar ruang terbuka hijau umum yaitu anisositik, diasitik, parasitik, anomositik. struktur stomata menunjukkan bahwa daun yang terdapat pada kawasan arboretum memiliki stomata yang besar sedangkan di luar ruang terbuka hijau umum memiliki stomata yang kecil. Keadaan cahaya dan suhu yang berbeda sangat mempengaruhi adanya variasi angka pada ukuran stomata, lobang stomata dan sel tetangga. Semakin jauh jarak tanaman dengan tempat yang ramai kendaraan semakin menurun pula ukuran stomata.

\section{DAFTAR PUSTAKA}

Fahn, A. 1991. Anatomi Tumbuhan. Yogyakarta: Universitas Gadjah Mada Press.

Hidayat, Estiti.1995. Anatomi Tumbuhan Berbiji. Bandung: ITB Press.

Khoiroh Y, Harijati N, Mastuti R, 2014. pertumbuhan serta hubungan kerapatan stomata dan berat umbi pada Amorphophallus muelleri Blume dan Amorphophallus variabilis Blume.Jurnal Biotropika. Vol 5:65-67.

Lakitan B.1993. Dasar-Dasar Fisiologi Tumbuhan. Jakarta: Raja Grafindo Persada.

Loveless A, R ,1991. Prinsip-prinsip Biologi Tumbuhan untuk Daerah Tropik dari Principles of Plant
Biology For The Tropics. Jakarta: Gramedia Pustaka Utama.

Marpaung, D.R.A.K, Pasaribu, N.Aththorick, T, 2013. Taxonomic study of pandanus (Pandanaceae) in swamp area, Aceh singkil. Jurnal natural. Vol 13:22-25.

Mulyani, S. 2006. Anatomi Tumbuhan.Yogyakarta: Kanisius.

Salisbury, Frank B, Ross, C.W, 1995. Fisiologi Tumbuhan. Bandung: ITB.

Sri Haryanti. 2010. Jumlah dan distribusi stomata pada daun Beberapa spesies tanaman dikotil dan monokotil. Buletin Anatomi dan Fisiologi, Vol 18 :21-28.

Sumardi I, Pudjoarianto A, 1994. Struktur dan Perkembangan Tumbuhan. Yogyakarta: Fakultas Biologi UGM.

Tambaru, E. A.I. Latunra dan S. Suhadiyah.2013. Peranan Morfologi dan Tipe Stomata Daun dalam Mengabsorpsi Karbondioksida pada Pohon Huta Kota UNHAS Makassar. Makassar: Universitas Hasanuddin.

Wahyuni, A.S. Tambaru, E, Latunra, A.I. 2014. Hubungan Jumlah Stomata Daun

Ketapang Terminalia catappa Linn dan Daun Jati Tectona grandis dengan Hasil

Absorbs CO di Hutan Kota. Makassar: Universitas Hasanuddin. 